Iwan Hermawan, Uus Ruswandi, Mohamad Erihadiana /_Ta'dib: Jurnal Pendidikan Islam,

Vol. 9 No. 1 (2020) 63-76

ISSN 1411-8173 | E-ISSN 2528-5092

https://ejournal.unisba.ac.id/index.php/tadib/article/view/6233

\title{
THE CONCEPT OF MANAGEMENT OF LEARNING MKWU PAI BASED ON MULTICULTURAL COMPONENTS
}

\author{
Iwan Hermawan ${ }^{1}$, Uus Ruswandi ${ }^{2}$, Mohamad Erihadiana ${ }^{3}$ \\ ${ }^{1}$ Universitas Singaperbangsa Karawang, ${ }^{2,3}$ Universitas Islam Negeri Sunan Gunung Djati Bandung \\ Email: iwan.hermawan@staff.unsika.ac.id,uusruswandi@uinsgd.ac.id, erihadiana@uinsgd.ac.id \\ DOI: https://doi.org/10.29313/tipi.v9i1.6233 \\ Submitted: June 03th, 2020. Approved: June 29th, 2020. Published: June 29th, 2020
}

\begin{abstract}
Multiculturalism means cultural diversity or cultural heterogeneity. It is undeniable that students who enter tertiary institutions come from different regions with different ethnicities, different cultural cultures which can be one of the problems that interfere in the learning process. The naming of different people as mentioned by Allah in the Qur'an seems to be a commandment that must be completed by humans themselves using scientific knowledge. Multicultural Education is habituation or cultural education that provides opportunities for all students regardless of gender, social class, ethnicity, race, ethnicity, religion, and culture. In the Qur'an, several verses explain multiculturalism, including in the QS. Al-Hujurat: 13, Q.S. Ar-Rum: 22. The goals of multicultural education are basically in harmony with character education which leads to one goal, namely good behavior or moral values as the main goal of the Islamic religion is revealed on earth. As a reference in implementing multicultural education, a learning management concept is needed based on the components or important elements that exist in a system to process the achievement of expected goals, namely 1) Strengthening similarities rather than differences, 2) Mutual trust and mutual understanding, 3) Tolerance of differences, 4) Discussion is not imposing opinion.
\end{abstract}

Keywords: Management; Learning; Component; Eduacation; Multicultural.

\begin{abstract}
Abstrak
Multikultural bermakna keragaman kultur atau heterogenitas kebudayaan. Tidak dapat dipungkiri bahwa mahasiswa yang masuk pada perguruan tinggi berasal dari berbagai daerah yang berbeda suku, berbeda kultur budayanya yang dapat menjadi salah satu permasalahan yang mengganggu dalam proses pembelajaran. Penamaan manusia yang berbeda-beda sebagaimana yang disebutkan Allah dalam Al-Qur'an seolah menjadi sebuah perintah yang harus diselesaikan oleh manusia itu sendiri dengan cara berilmu pengetahuan. Pendidikan Multikutural adalab pendidikan pembiasaan atau pembudayaan yang memberikan kesempatan pada semua mahasiswanya tanpa memandang jenis kelamin, kelas sosial, ras, suku, agama, dan budayanya. Dalam Al-Qur'an terdapat beberapa ayat yang menjelaskan tentang multikultural, antara lain terdapat dalam Q.S. Al-Hujurat: 13, Q.S. Ar-Rum: 22. Tujuan pendidikan multikultural ini pada dasarnya selaras pendidikan karakter yang bermuara pada satu tujuan yaitu pada perilaku yang baik atau akblak karimah sebagaimana pokok tujuan agama Islam diturunkan dimuka bumi ini. Sebagai acuan dalam menerapkan pendidikan multikultural tersebut diperlukan sebuah konsep pengelolaan pembelajaran berdasarkan pada komponenkomponen atau unsur-unsur penting yang ada pada suatu sistem untuk memproses pencapaian tujuan yang diharapkan, yaitu 1) Memperkuat persamaan daripada perbedaan, 2) Saling percaya dan saling pengertian, 3) Toleransi terhadap perbedaan, 4) Berdiskusi bukan memaksakan pendapat.
\end{abstract}

Kata Kunci: Pengelolaan; Pembelajaran; Komponen; Pendidikan; Multikultural. 


\section{PENDAHULUAN}

Ide pendidikan multikultural adalah berawal dari gerakan-gerakan yang muncul paska perang dunia ke II, dimana banyaknya migrasi penduduk dunia yang tidak mendapatkan hak-haknya karena perbedaan kelas sosial, etnis, ras, suku, agama, dan budayanya.

Istilah multikulturalisme marak digunakan pada tahun 1950 di Kanada. Istilah ini diderivasi dari kata multicultural yang dipopulerkan surat kabar-surat kabar di Kanada, yang menggambarkan masyarakat Montreal sebagai masyarakat multikultural dan multilingual (Irhandayaningsih, 2012).

Di Amerika Serikat paham multikultural telah lahir dari perlawanan terhadap politik segregasi yang membedakan antara kebudayaan kulit putih dan kebudayaan kulit hitam. Adalah Dr. Martin Luther King yang pada tahun 1965 menggusur paham segregasi ketika dia memimpin demonstrasi di Washington D.C. Gerakan penghapusan segregasi tersebut ditegaskan dalam Kongres Pendidikan Tinggi se-Amerika di University of Illinois pada tahun 1990. Dengan demikian dapat dikatakan politik dan praksis segregasi dalam kehidupan Amerika termasuk di dalam dunia pendidikannya telah dihapuskan (Tilaar, 2014).

Multikultural sendiri diartikan sebagai keragaman kebudayaan, aneka kesopanan (Mahfud, 2011, p. 22).

Dalam Kamus Besar Bahasa Indonesia, pengertian multikultural bersifat keberagaman budaya, sedangkan multikulturalisme itu adalah gejala pada seseorang atau suatu masyarakat yang ditandai oleh kebiasaan menggunakan lebih dari satu kebudayaan (Pusat Bahasa Kemdikbud, 2011).

Dengan demikian dapat dikatakan bahwa multikulturalisme adalah cara pandang manusia terhadap perbedaan- perbedaan dalam kehidupannya yang berupa nilai-nilai, norma-norma, budaya, adat kebiasaan dan lain-lain.

Secara sederhana multikultural berarti "keberagaman budaya". Istilah multikultural ini sering digunakan untuk menggambarkan tentang kondisi masyarakat yang terdiri atas keberagaman agama, ras, bahasa, dan budaya yang berbeda. Selanjutnya, dalam khasanah keilmuan istilah multikultural ini dibedakan ke dalam beberapa ekspresi yang lebih sederhana, seperti pluralitas (plurality) mengandaikan adanya "hal-hal yang lebih dari satu (many)", keragaman (diversity) menunjukkan bahwa keberadaan yang "lebih dari satu" itu berbeda-beda, heterogen, dan bahkan tidak dapat disamakan, dan multikultural (multicultural) itu sendiri (Hanafi, 2016).

Pada dasarnya perbedaan dan keragaman pada manusia itu adalah sunnatullah (ketetapan Allah), sebagaimana tercantum dalam Q.S. Hud: 118.

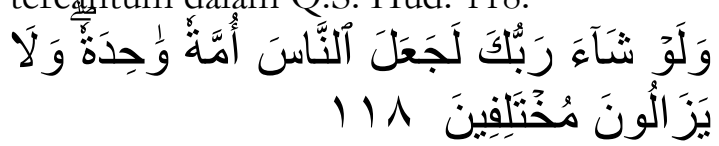

"Jikalau Tuhanmu menghendaki, tentu Dia menjadikan manusia umat yang satu, tetapi mereka senantiasa berselisih pendapat".

Namun demikian Allah menyiratkan dalam ayat berikutnya, bahwa perbedaan itu sebenarnya adalah rahmat.

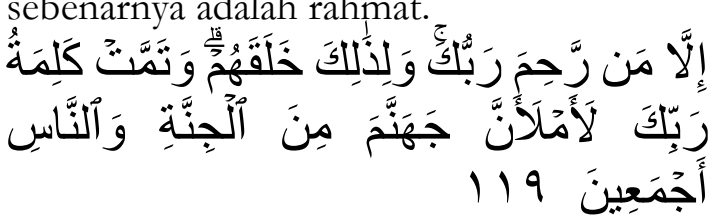

"Kecuali orang-orang yang diberi rahmat oleh Tuhanmu. Dan untuk itulah Allah menciptakan mereka. Kalimat Tuhanmu (keputusan-Nya) telah ditetapkan: sesungguhnya Aku akan memenuhi neraka Jahannam dengan jin dan manusia (yang durhaka) semuanya" (Q.S. Hud: 19).

Menurut Tilaar, Multikulturalisme adalah "konsep pembudayaan, dan oleh karena proses pendidikan adalah proses pembudayaan, maka masyarakat 
multikultural dapat diciptakan melalui proses pendidikan"(Wihardit, 2010).

Model pendidikan yang tepat untuk menanamkan nilai-nilai kebhinekaan adalah pendidikan multikultural. Karena Indonesia rentan terhadap berbagai konflik berbasis SARA, maka kehadiran pendidikan multikultural menjadi sesuatu yang urgen di setiap institusi pendidikan. Terlebih lagi dijumpai fakta masuknya doktrin radikalisme di kalangan pelajar sekolah (Ashadi, 2017).

Menurut Nurul Asna dalam majalah Majalah Inovasi. Kurikulum edisi IV tahun 2003, yang dikutip oleh idi Warsah menyebutkan bahwa semangat yang paling penting dari multikulturalisme adalah living together as one society (hidup bersama sebagai suatu masyarakat). Ide ini muncul karena dorongan akan kenyataan bahwa dunia, sejak lima puluh tahun yang lalu bergerak menjadi dusun global (global village). Dunia sekarang tidak lagi merupakan tempat dimana satu wilayah hanya dihuni oleh satu kelompok etnis, budaya, dan agama tertentu saja. Keragaman ini muncul dan menjadi conditio sine qua non pada sebuah masyarakat global. Oleh karena itu, bagi masyarakat Indonesia yang plural mesti harus menangkap konsep ini sebagai sebuah fenomena yang realistis. Indonesia adalah masyarakat majemuk, baik secara horizontal maupun vertikal. Kendatipun ada semangat provinsialisme akibat otonomi daerah tapi melestarikan sikap monokulturalisme bukanlah sikap yang bijak untuk saat sekarang (Warsah, 2017).

Dalam Al-Qur'an surat Al-Hujurat ayat 13, Allah SWT. menyebutkan tentang penciptaan manusia yang berbeda-beda suku dan bangsa. Ini menegaskan tentang adanya multikultural pada diri manusia yang memang sengaja diciptakan demikian agar mereka dapat saling mengenal dan saling menutupi dari kelebihan dan kekurangan masing-masing.

Agama yang dibawa oleh rasulullah SAW. adalah rahmatan lil "alamin (rahmat bagi semesta alam) sebagaimana tercantum dalam Q.S Al-Anbiya ayat 107. Selain itu agama Islam juga sangat memuliakan dan menjunjung tinggi hak-hak asasi manusia tanpa membedakan gender, ras, warna kulit, bahasa, bangsa, dan status sosial, sebagaimana tercantum dalam Q.S. Al-Isra ayat 70 .

Jika dikaitkan dengan konsep pendidikan, maka sebenarnya manusia mempunyai hak sama dimata Allah SWT. untuk mendapatkan hak pendidikan yang layak tanpa ada dikotomi apapun.

Inilah pentingnya pembelajaran multikultural dalam pendidikan, agar semuanya mendapatkan hak yang sama dalam memperoleh ilmu pengetahuan sebagai penuntun dalam mengarungi hidup di dunia dan bekal untuk kehidupan akhirat kelak.

Menurut Paul C. Gorski ada tiga tujuan utama pendidikan multikultural, yaitu:

1. Meniadakan diskriminasi pendidikan, memberi peluang sama bagi setiap anak untuk mengembangkan potensinya (tujuan instrumental);

2. Menjadikan anak bisa mencapai prestasi akademik sesuai potensinya (tujuan terminal internal);

3. Menjadikan anak sadar sosial dan aktif sebagai warga masyarakat lokal, nasional, dan global (tujuan terminal akhir eksternal) (Zamroni, 2011).

Dan sebagai pertimbangan dalam proses pembelajaran multikultural, Banks membagi ke dalam 6 (enam) faktor atau komponen multikultur, yaitu;" 1) gender, 2) etnic, 3) social class, 4) religion, 5) race exceptionality, dan 6) other variables (Sulalah, 2011).

Landasan untuk penyelenggaraan pendidikan multikultural di Indonesia terdapat dalam pasal 4 butir (1) Undangundang Nomor 20 tahun 2003, disebutkan "Pendidikan diselenggarakan secara demokratis dan berkeadilan serta tidak diskriminatif dengan menjunjung tinggi hak 
asasi manusia, nilai keagamaan, nilai kultural, dan kemajemukan bangsa" (Tim Fokusmedia, 2015).

Berdasarkan landasan itulah, para pengelola pendidikan menerapkan konsep pendidikan multikultural di satuan pendidikannya masing. Selain itu pula banyak penelitian yang membahas tentang pendidikan multikultural ini secara umum dengan melihat perbedaan kelas sosial, etnis, ras, suku, agama, dan budayanya. Sedangkan untuk penelitian-penelitian yang membahas komponen-komponen secara khusus belumlah banyak, apalagi yang spesifik mengkaitkan dengan agama. Oleh karenanya dalam penelitian ini lebih spesifik membahas tentang komponen-komponen pendidikan multikultural yang terdapat dalam Al-Qur'an dan Hadis.

Ada beberapa pesan Allah SWT. dalam Al-Qur'an yang dapat menjadi pertimbangan dalam menetapkan komponen-komponen Multikultural dalam pendidikan dan pembelajaran, antara lain terdapat dalam firman Allah swt dalam Q.S. Al-Hujurat: 13.

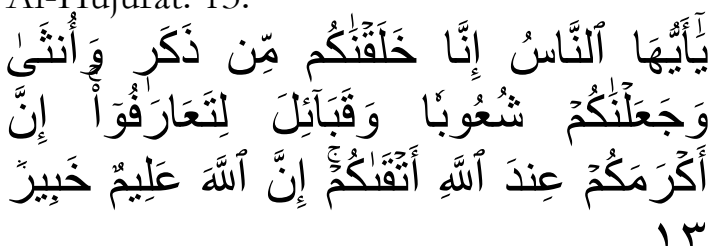

"Hai manusia, sesungguhnya Kami menciptakan kamu dari seorang laki-laki dan seorang perempuan dan menjadikan kamu berbangsa-bangsa dan bersuku-suku supaya kamu saling kenal-mengenal. Sesungguhnya orang yang paling mulia diantara kamu disisi Allah ialah orang yang paling takwa diantara kamu. Sesungguhnya Allah Maha Mengetahui lagi Maha Mengenal"'. (Q.S. Al-Hujurat: 13)

Dalam tafsir fathul qadir jilid 10 disebutkan bahwa sebenarnya mereka (manusia) itu sama karena terhubung dengan nasab yang sama, dan terhimpun pada satu bapak dan satu ibu yang sama. Tidak ada celah untuk membanggakan garis keturunan (Asy-Syaukani, n.d., p. 492 [10]).
Demikian juga dengan pendapat AthThabari yang menyatakan bahwa walaupun manusia berbeda suku dan bangsa, namun mereka itu awalnya adalah satu nasab supaya mereka menjadi serasi. Walaupun sebagian ada yang ber-nasab dengan sebagian lainnya dengan nasab yang jauh, dan sebagian ada yang ber-nasab dengan sebagian lainnya dengan nasab yang dekat. Orang yang bernasab dengan nasab yang jauh adalah warga bangsa-bangsa, sedangkan orang yang bernasab dengan nasab yang dekat adalah warga kabilah atau suku (Ath-Thabari, 2009, p. 767).

Hidup berbangsa-bangsa, bersukusuku bisa saja menimbulkan permusuhan dan peperangan, karena orang telah lupa kepada nilai ketakwaan. Di ujung ayat ini Tuhan menyatakan bahwa Tuhan Maha Mengetahui, bahwasanya bukan sedikit kebangsaan menimbulkan 'ashabiyah jahiliyah, pongah dan bangga karena mementingkan bangsa sendiri, sebagai perkataan orang Jerman di kala Hitler naik: "Duitschland ubber alles!" (Jerman di atas dari segala-galanya). Tuhan mengetahui bahwa semuanya itu palsu belaka, Tuhan mengenal bahwa setiap bangsa ada kelebihan sebanyak kekurangan, ada pujian sebanyak cacatnya. Islam telah menentukan langkah yang akan ditempuh dalam hidup; "Yang semulia-mulia kamu ialah barangsiapa yang paling takwa kepada Allah!” (Hamka, 1982, p. 6836 [9]).

Allah memberi tahu manusia bahwa Dia menciptakan mereka dari satu jiwa, menjadikan pasangannya dari jiwa itu, yaitu Adam dan Hawa. Dia juga menjadikan mereka berbangsa-bangsa dan bersukusuku. Ayat tersebut datang setelah ayat-ayat yang melarang untuk mengejek, menghina, berburuk sangka, dan ghibah (Al-Khalidi, 2017, p. 113 [6])

Selain komponen-komponen suku, bangsa, dan agama sebagaimana tercantum dalam Q.S. Al-Hujurat: 13 tersebut diatas, firman Allah yang lain tentang komponen- 
komponen multikultural juga terdapat dalam Q.S. Ar-Rum: 22.

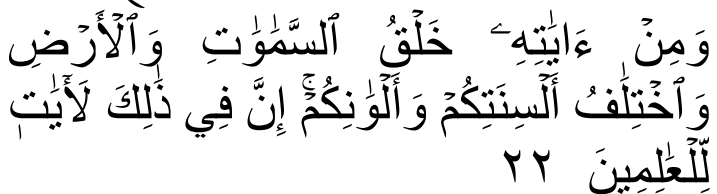

"Dan di antara tanda-tanda kekuasaan-Nya ialah menciptakan langit dan bumi dan berlain-lainan bahasamu dan warna kulitmu. Sesungguhnya pada yang demikan itu benar-benar terdapat tanda-tanda bagi orang-orang yang mengetahui". (Q.S. ArRum: 22).

Pada ayat ini, Allah SW'T. menyebutkan secara jelas tentang komponen-komponen multikultural, yaitu bahasa dan warna kulit yang merupakan tanda-tanda bagi orang yang mengetahui. Hal ini menandakan bahwa Allah SWT. menciptakan manusia itu berbeda-beda dan tidak ada yang sama. Dengan kalimat penegas dari Allah "terdapat tanda-tanda bagi orang yang mengetahui" adalah bermakna agar manusia bisa belajar dengan perbedaan-perbedaan itu.

Menurut Hamka dalam tafsir AlAzhar menjelaskan bahwa bahasa di dunia ini sangat banyak termasuk bahasa daerah yang ada di Indonesia tidak kurang dari 300 bahasa. Selain itu ada juga perbedaan warna kulit dengan karakter dan kepribadiannya masing-masing. Maka Allah menjelaskan diujung ayat tersebut tentang pentingnya mempunyai ilmu pengetahuan sebagaimana pada penutup ayat sebelumnya terdapat anjuran Allah untuk berpikir (Hamka, 1982, pp. 5505-5506).

Walaupun dari keturunan yang sama, dari jenis yang sama, tipe yang sama dan dapat berbicara namun manusia bisa menjadi berbeda antara yang satu dengan lainnya. Hal ini tidak akan dipahami kecuali oleh orang-orang yang berpikir dan berilmu (Asy-Syaukani, n.d., p. 670).

Dengan demikian, sesungguhnya perbedaan bahasa dan warna kulit manusia adalah untuk menunjukan kekuasaan Allah. Allah lah yang mengajarkan bahasa-bahasa yang berbeda tersebut. Sedangkan perbedaan warna kulit adalah untuk menunjukan perbedaan manusia yang satu dengan yang lainnya walaupun sama-sama mempunyai mata, alis, hidung, pelipis, mulut, dan lain-lain. Seandainya Allah menciptakan manusia yang sama dan memiliki semua kesamaan, maka pasti akan menimbulkan kebingungan (Al-Sheikh, 2005, p. 365 [6]).

Perbedaan-perbedaan itu menjadi ciri khas masing-masing yang bisa dikenali sehingga bisa dibedakan antara satu individu dengan individu yang lain. Tanda-tanda bukti itu bisa dipastikan tidak samar sedikit pun bagi setiap makhluk yang berakal, baik itu dari kalangan bangsa malaikat, manusia, maupun jin (Az-Zuhaili, 2013, p. 89 [11]). SWT.

Hal ini dipertegas oleh firman Allah

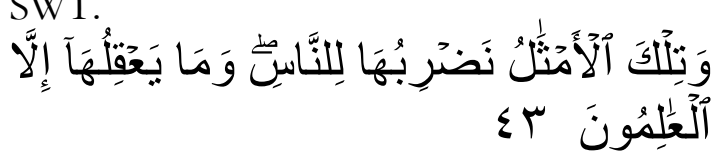

"Dan perumpamaan-perumpamaan ini

Kami buat untuk manusia; dan tiada yang memahaminya kecuali orang-orang yang berilmu" (Q.S. Al-Ankabut: 43).

Selain dari ayat-ayat Al-Qur'an tersebut diatas, juga diperkuat oleh hadishadis rasulullah SAW. yang dapat menjadi landasan untuk pelaksanaan pendidikan dan proses pembelajaran multikultural pada Mata Kuliah Wajib Umum Pendidikan Agama Islam (MKWU PAI) di Perguruan Tinggi Umum (PTU).

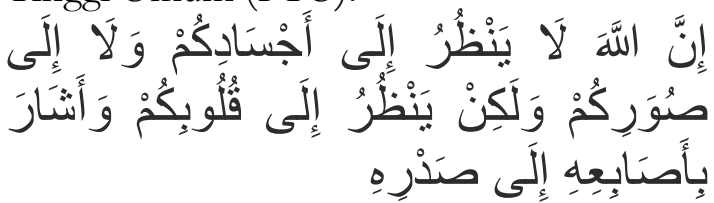

"Sesungguhnya Allah tidak melihat kepada tubuh dan rupa kalian, akan tetapi Allah melihat kepada hati kalian". (H.R. Muslim)

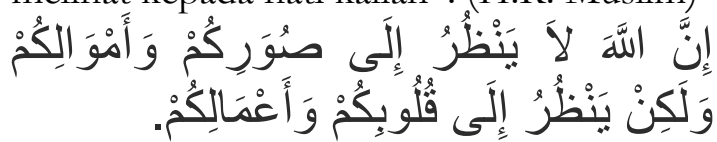
"Sesungguhnya Allah SWT tidak memandang pada bentuk rupa dan hartaharta kalian, melainkan memandang pada 
hati dan amal-amal kalian". (H.R. Ibnu Hibban)

Dari kedua hadis ini rasulullah SAW menjelaskan tentang perbedaan postur dan bentuk tubuh dan penampilan, serta status sosial yang berkaitan dengan harta bukanlah sesuatu yang akan dilihat dan dinilai oleh Allah, karena yang akan dilihat dan dinilai oleh Allah berkaitan dengan baik dan buruknya seorang manusia adalah berada pada hatinya.

Berdasarkan pada ayat-ayat AlQur'an dan Hadis-Hadis tersebut diatas maka secara sederhana pendidikan Multikutural adalah pendidikan yang memberikan kesempatan tanpa memandang jenis kelamin, kelas sosial, etnis, ras, agama, dan budayanya. Walaupun pengertian tersebut sangat sederhana, pendidikan multikultural harus diberi makna dan sesuai dengan fungsi pendidikan nasional. Oleh karenanya pendidikan multikultural memerlukan pengkajian yang mendalam, pengisian dan pengayaan konsep yang sempurna, dan penerapan yang cermat (Tobroni, 2007).

Pembelajaran MKWU PAI di PTU dengan mahasiswa yang multikultural memerlukan pengelolaan pembelajarannya berdasarkan pada komponen-komponen multikulturnya, antara lain jenis kelamin, kelas sosial, etnis, ras, suku dan budayanya.

Konsep pengelolaan pembelajaran MKWU PAI di PTU berdasarkan komponen-komponen multikultural yang akan dibahas pada penelitian ini adalah 1) Mencari dan memperkuat persamaan daripada perbedaan (Q.S. Ali Imran: 64), 2) Saling Percaya dan Saling Pengertian (Q.S. Al-Hujurat: 12), 3) Toleransi (Q.S. AlBaqarah: 109), dan 4) Diskusi (Q.S. AnNahl: 125).

\section{Metode Penelitian}

Kegiatan penelitian ini bersifat kepustakaan (Library Research) atau studi kepustakaan yang berarti segala usaha yang dilakukan oleh peneliti untuk menghimpun informasi yang relevan dengan topik atau masalah yang akan atau sedang diteliti. Informasi itu dapat diperoleh dari bukubuku ilmiah, laporan penelitian, karangankarangan ilmiah, tesis dan disertasi, peraturan-peraturan, ketetapan-ketetapan, buku tahunan, ensiklopedia, dan sumbersumber tertulis baik tercetak maupun elektronik lain.(Hermawan, 2019b, p. 167) sehingga data yang di peroleh adalah berasal dari buku, tafsir dan jurnal yang relevan dengan pokok masalah di atas.

Library research memanfaatkan sumber perpustakaan untuk memperoleh data penelitiannya. Tegasnya riset pustaka membatasi kegiatannya hanya pada bahanbahan koleksi perpustakaan saja tanpa memerlukan riset lapangan. Riset pustaka tidak hanya sekedar urusan membaca dan mencatat literatur atau buku-buku sebagaimana yang sering dipahami banyak orang selama ini. apa yang disebut riset pustaka atau sering juga disebut studi pustaka, ialah rangkaian kegiatan yang berkenaan dengan metode pengumpulan data pustaka, membaca dan mencatat serta mengolah bahan penelitian (Hermawan, 2019a, p. 134).

Penelitian ini dilakukan dengan menganalisis beberapa ayat Al-Qur'an dan Hadits yang berkaitan dengan komponenkomponen pendidikan multikultural, kemudian diolah dan disimpulkan dengan mengkaitkan teks pada referensi tafsir dan konteks yang berdasarkan pemahaman penulis. Pendekatan yang digunakan dalam penelitian ini adalah pendekatan deskriptifanalitik. Penelitian ini mengkaji bagaimana Al-Qur'an membahas tentang komponenkomponen pendidikan multikultural, dengan mengaitkan antara ayat satu dengan ayat lainnya sehingga membentuk satu pemahaman yang utuh. 


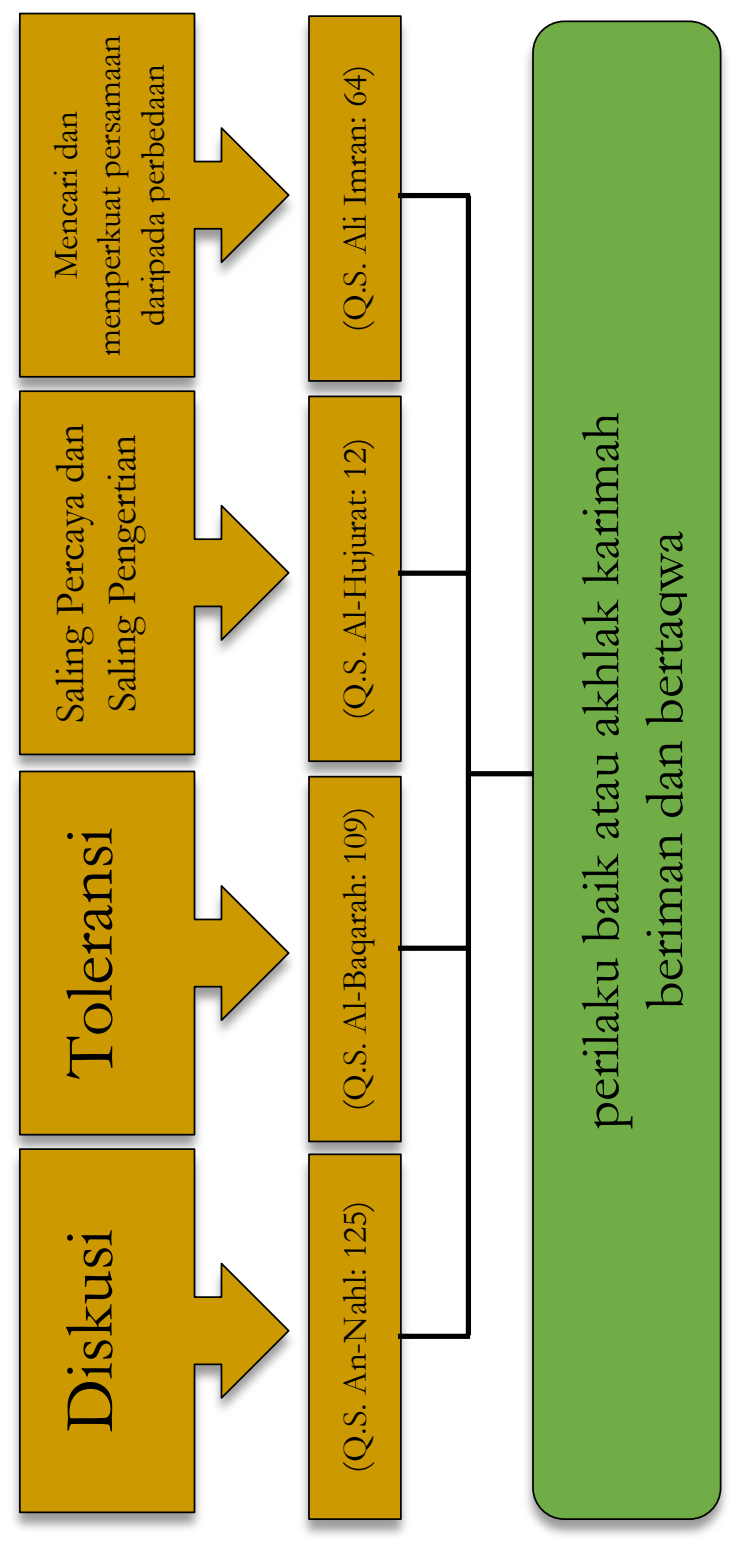

\section{Hasil dan Pembahasan}

Pengelolaan pembelajaran terdiri dari 2 (dua) kata, yaitu "Pengelolaan" dan "Pembelajaran". Dalam Kamus Besar Bahasa Indonesia (Pusat Bahasa Kemdikbud, 2011), kata Pengelolaan, mempunyai 4 pengertian, yaitu:

1. Pengelolaan adalah proses, cara, perbuatan mengelola;

2. Pengelolaan adalah proses melakukan kegiatan tertentu dengan menggerakkan tenaga orang lain;

3. Pengelolaan adalah proses yang membantu mermuskan kebijaksanaan dan tujuan organisasi;
4. Pengelolaan adalah proses yang memberikan pengawasan pada semua hal yang terlibat dalam pelaksanaan kebijaksanaan dan pencapaian tujuan.

Dengan demikian bahwa pengelolaan adalah pemanfaatan dan pengendalian semua sumberdaya untuk mencapai tujuan yang diharapkan.

Pembelajaran adalah hubungan timbal balik antara peserta didik dan pendidik dalam proses dan suasana belajar dengan menggunakan berbagai sarana dan prasarana belajar.

Sedangkan kata komponen mempunyai arti bagian dari keseluruhan atau unsur yang membentuk suatu sistem atau kesatuan. Oleh karena itu, komponen merupakan unsur-unsur penting yang ada pada suatu sistem untuk memproses pencapaian tujuan yang diharapkan (Pusat Bahasa Kemdikbud, 2011).

Keberhasilan suatu tujuan tergantung dari pengelolaan komponen-komponen yang ada menjadi sumber daya yang saling mendukung dan membentuk suatu sistem dan kesatuan yang utuh menjadi konsep yang dapat di implementasikan sehingga dapat menghasilkan model dan metode, media dan tujuan yang tepat.

Multikultural dapat dirumuskan sebagai wujud kesadaran tentang keanekaragaman cultural, hak-hak asasi manusia serta pengurangan atau penghapusan jenis prasangka atau prejudice untuk suatu kehidupan masyarakat yang adil dan maju. Pendidikan multicultural juga dapat dijadikan instrument strategis untuk mengembangkan kesadaran atas kebanggaan seseorang terhadap bangsanya (Hidayatullah, 2012).

\section{Komponen-komponen Pendidikan Multikultural dalam Al-Qur'an}

Sebenarnya, terdapat tiga istilah yang sering digunakan secara bergantian untuk menggambarkan masyarakat yang terdiri keberagaman tersebut, yaitu pluralitas (plurality), keragaman (diversity), dan multikultural (multicultural). Ketiga ekspresi 
itu sesungguhnya tidak merepresentasikan hal yang sama, walaupun semuanya mengacu kepada adanya "ketidaktunggalan" (Warsah, 2017).

Berdasarkan persepsi umum tentang multikultural selalu terkait dengan perbedaan jenis kelamin, kelas sosial, etnis, ras, suku dan budayanya. Maka pada proses pembelajaran itupun harus memperhatikan komponen-komponen tersebut agar konsep, model, metode, media, dan strategi dapat sesuai dengan tujuan pembelajaran yang diharapkan.

Menurut Bikhu Parekh dalam bukunya Rethinking Multiculturalism yang dikutip oleh Ana Irhandayaningsih, ada tiga komponen multikulturalisme, yakni kebudayaan, pluralitas kebudayaan, dan cara tertentu untuk merespons pluralitas itu. Multikulturalisme bukanlah doktrin politik pragmatik, melainkan cara pandang kehidupan manusia. Karena hampir semua negara di dunia tersusun dari aneka ragam kebudayaan artinya perbedaan menjadi asasnya dan gerakan manusia dari satu tempat ke tempat lain di muka bumi semakin intensif, maka multikulturalisme itu harus diterjemahkan ke dalam kebijakan multikultural sebagai politik pengelolaan perbedaan kebudayaan warga negara (Irhandayaningsih, 2012).

Sebagaimana disebutkan dalam Q.S. Al-Hujurat: 13 diatas, komponenkomponen multikultural terdiri dari Suku, bangsa dan jenis kelamin. Demikian juga komponen-komponen multikultural yang terdapat dalam Al-Qur'an Ar-Rum: 27 adalah bahasa dan warna kulit (ras).

Jika dikaji lebih jauh, sebenarnya multikultural tersebut berasal dari perbedaan penamaan manusia yang disebutkan Allah di dalam Al-Qur'an dengan nama yang berbeda-beda.

Terdapat 5 (lima) penyebutan dari Allah SWT. terhadap manusia, yaitu: bani Adam (Q.S. Al-A'raf: 31), basyar (Q.S. AlMu'minun: 33), insan (Q.S. Ar-Rahman: 3-
4), an-naas (Q.S. Al-Baqarah: 21), dan abdun (Q.S. Saba: 9).

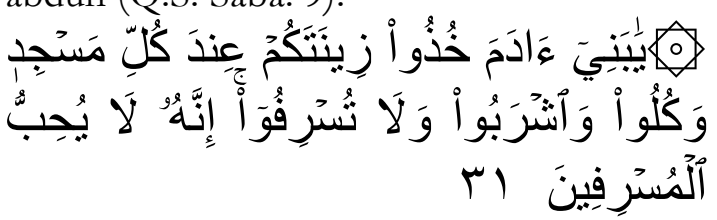

"Hai anak Adam, pakailah pakaianmu yang indah di setiap (memasuki) mesjid, makan dan minumlah, dan janganlah berlebihlebihan. Sesungguhnya Allah tidak menyukai orang-orang yang berlebihlebihan" (Q.S. Al-A'raf: 31)

Menurut Asy-Syaukani dalam tafsir fathul qadir, khithab pada ayat ini adalah untuk semua manusia walaupun diturunkan karena sebab yang khusus, karena penyimpulannya berdasarkan keumuman lafaz bukan berdasarkan kekhususan sebab (Asy-Syaukani, n.d., p. 54 [4]).

Demikian juga menurut Buya Hamka dalam Tafsir Al-Azhar, bahwa Allah SWT. menyampaikan seruan kepada seluruh anak adam dapatlah kita pahamkan bahwa Agama Islam ini bukanlah khusus untuk suatu bangsa saja, melainkan benarlah Muhammad SAW. itu rahmat bagi seluruh alam, baik laki-laki maupun perempuan (Hamka, 1982, p. 2349 [4]).

Sebutan bani adam ini adalah karena berkaitan dengan historis penciptaan manusia yang berasal dari satu keturunan yaitu Nabi Adam AS, sebagai manusia pertama.

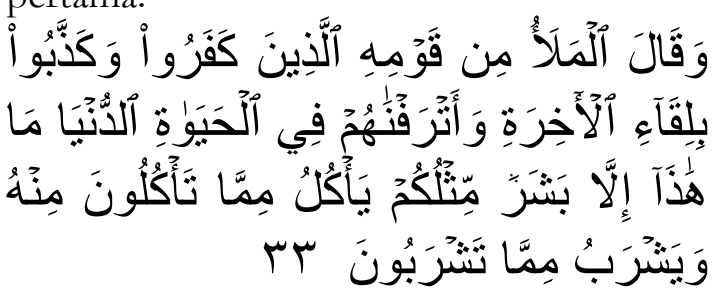

"Dan berkatalah pemuka-pemuka yang kafir di antara kaumnya dan yang mendustakan akan menemui hari akhirat (kelak) dan yang telah Kami mewahkan mereka dalam kehidupan di dunia: "(Orang) ini tidak lain hanyalah manusia seperti kamu, dia makan dari apa yang kamu 
makan, dan meminum dari apa yang kamu minum" (Q.S. Al-Mu'minun: 33).

Dalam ayat ini Allah SWT. mengisyaratkan bahwa manusia secara biologis atau bentuk fisik itu pada dasarnya sama dan sederajat tidak dibedakan karena status sosial dan harta. Sebagaimana Quraish Shihab mengatakan bahwa kata basyar terambil dari akar kata yang pada mulanya berarti penampakan sesuatu dengan baik dan indah. Dari akar kata yang sama, lahir kata basyarah yang berarti kulit. Manusia dinamai basyar karena kulitnya tampak jelas, dan berbeda dengan kulit binatang yang lain (Shihab, 2007, p. 367).

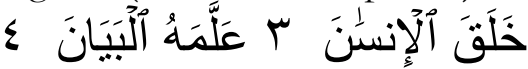

"Dia menciptakan manusia. Mengajarnya pandai berbicara" (Q.S. Ar-Rahman: 3-4).

Kata insan ini digunakan dalam AlQuran untuk menunjuk kepada manusia dengan seluruh totalitasnya, jiwa dan raga. Manusia yang berbeda antara seorang dengan yang lain, akibat perbedaan fisik, mental dan kecerdasan. Kata al-insan dituturkan sampai 65 kali dalam Al-Quran dan dikelompokkan ke dalam tiga kategori: (a) al-insan dihubungkan dengan khalifah sebagai penanggung amanah (Q.S. AlAḥzab: 72), (b) al-insan yang dihubungkan dengan predisposisi negatif dalam diri manusia misalnya sifat keluh kesah, kikir (Q.S. Al-Ma'arij: 19-21), (c) al-insan dihubungkan dengan proses penciptaan yang terdiri dari unsur materi dan nonmateri (Q.S. Al-Hijr: 28-29). Semua konteks al-insan ini merujuk pada sifat-sifat manusia psikologis dan spiritual. Berdasarkan penjelasan tersebut maka dalam aspek psikologis manusia dikenal dengan sebuatan Al-Insan (Shihab, 2007, p. 369).

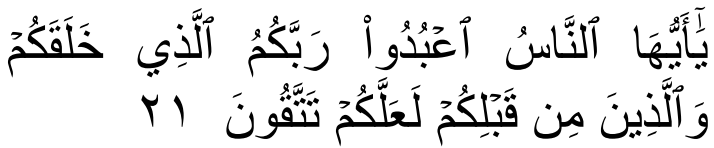

"Hai manusia, sembahlah Tuhanmu yang telah menciptakanmu dan orang-orang yang sebelummu, agar kamu bertakwa" (Q.S. AlBaqarah: 21).

Kata an-naas disebut sebanyak 240 kali dalam Al-Quran mengacu kepada manusia sebagai makhluk sosial dengan karakteristik tertentu misalnya mereka mengaku beriman padahal sebenarnya tidak (Q.S. Al-Baqarah; 8) (Supadie \& Sarjuni, 2011, p. 137). An-Naas menunjukkan pada eksistensi manusia sebagai makhluk sosial secara keseluruhan Allah telah menciptakan manusia dalam bentuk struktur yang sempurna (Arifin, 2014, p. 42). Berdasarkan penjelasan inilah dari aspek sosiologis manusia dikenal dengan sebutan An-Naas.

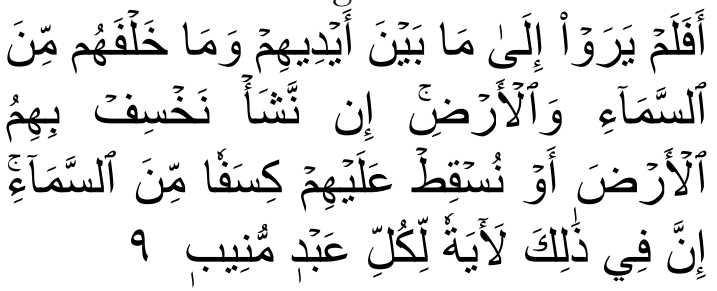

"Maka apakah mereka tidak melihat langit dan bumi yang ada di hadapan dan di belakang mereka? Jika Kami menghendaki, niscaya Kami benamkan mereka di bumi atau Kami jatuhkan kepada mereka gumpalan dari langit. Sesungguhnya pada yang demikian itu benar-benar terdapat tanda (kekuasaan Tuhan) bagi setiap hamba yang kembali (kepada-Nya)" (Q.S. Saba: 9)

'Abdun artinya hamba yang pandai dan cerdik, disambung dengan kata muniib yang memiliki arti yang kembali kepada Allah (Al-Sheikh, 2005, p. 553 [6]). Selain itu kata muniib dapat terambil dari kata annawb yang pada mulanya berarti turun, kemudian maknanya berkembang sehingga dipahami juga dalam arti kembali, yakni kembali ke posisi semula setelah ditinggalkan. Ini mengandung makna intropeksi dan menyesali perbuatan lalu memperbaiki diri. Karena itu, kata ini juga dipahami dalam arti bertobat dan kembali kepada Allah. Berdasarkan penjelasan inilah dalam aspek teologis manusia dikenal 
dengan sebutan 'Abdun (Shihab, 2008, p. 352 [11]).

Karena perbedaan komponenkomponen itulah, maka diperlukan suatu konsep dalam pengelolaan pembelajaran terutama pembelajaran MKWU PAI, agar tercapai maksud dan tujuan pembelajaran itu sendiri.

\section{Mencari dan memperkuat persamaan daripada perbedaan \\ Al-Quran menghendaki umat} manusia menerima perbedaan sebagai eksistensi kehidupan. Perbedaan adalah ciptaan Allah swt, dan semua ciptaan Allah adalah anugerah terindah untuk manusia dan makhluk lainnya. Ini menunjukkan bahwa kehidupan ini menjadi indah dengan perbedaan dan menjadi nyaman dengan kebersamaan. Keragaman merupakan potensi strategis untuk mewujudkan pembangunan dan sekaligus sebagai rahmat Allah SWT. Keragaman merupakan kekuatan atau energi untuk membangun kebersamaan. Dengan adanya kebersamaan tercipta peluang atau kesempatan untuk mengekspresikan diri, hidup berdampingan, dan bekerjasama antar berbagai kelompok masyarakat.

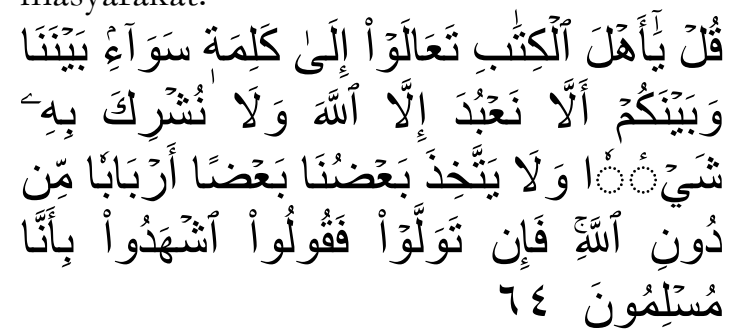

Katakanlah: "Hai Ahli Kitab, marilah (berpegang) kepada suatu kalimat (ketetapan) yang tidak ada perselisihan antara kami dan kamu, bahwa tidak kita sembah kecuali Allah dan tidak kita persekutukan Dia dengan sesuatupun dan tidak (pula) sebagian kita menjadikan sebagian yang lain sebagai tuhan selain Allah". Jika mereka berpaling maka katakanlah kepada mereka: "Saksikanlah, bahwa kami adalah orang-orang yang berserah diri (kepada Allah)". (Q.S. Ali Imran: 64)
Ayat ini menjelaskan tentang bagaimana cara menghadapi perbedaan untuk mencapai kesepakatan bersama (kalimatun sawa), sehingga bisa fokus pada sisi persamaannya, bukan fokus pada perbedaannya.

Keberhasilan proses pembelajaran multikultural terdapat pada faktor kesamaan pada pendidik dan peserta didik atau peserta didik dengan peserta didik lainnya. Semakin banyak kesamaan maka semakin terbuka keberhasilan pembelajaran karena tidak ada konflik.

Sebagai ilustrasi dari perbedaan adalah masyarakat Indonesia yang berbedabeda suku, bahasa bahkan pulau, tapi bisa bersatu dengan adanya bahasa kesatuan yaitu bahasa Indonesia yang kemudian mempunyai semboyan bhineka tunggal ika (berbeda-beda tetapi satu jua).

Sebagai seorang pendidik harus dapat mencari peluang persamaan pada para peserta didiknya dibanding mencari-cari perbedaan. Persamaan dimaksud bukan berarti tidak boleh berkompetisi dalam hal prestasi tapi lebih mengarahkan agar peserta didik kompak dan semangat dalam belajar.

Berikan mereka motivasi agar jangan menyerah, ketika melihat kemampuan temannya lebih dari dirinya. Sebagaimana rasulullah SAW. bersabda:

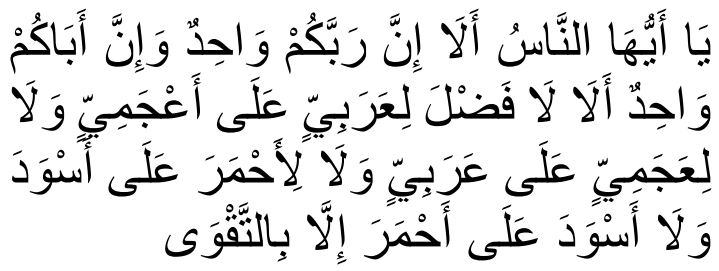

"Wahai sekalian manusia! Rabb kalian satu, dan ayah kalian satu, ingat! Tidak ada kelebihan bagi orang arab atas orang ajam dan bagi orang ajam atas orang arab, tidak ada kelebihan bagi orang berkulit merah atas orang berkulit hitam, bagi orang berkulit hitam atas orang berkulit merah kecuali dengan ketakwaan" (HR. Imam Ahmad). 


\section{Saling Percaya dan Saling Pengertian}

Rasa saling percaya akan menggugah antusiasme dan meninggikan motivasi dalam menjalankan suatu aktivitas. Setiap orang tidak menutup kemungkinan berbuat suatu kesalahan, apabila hal itu terjadi maka disinilah akan terlihat rasa saling percaya itu. Bukan penghakiman atau penghinaan yang diberikan kepada mereka yang berbuat salah dalam menjalankan suatu tugas yang dipercayakan, melainkan tawaran bantuanlah yang seharusnya diberikan kepada mereka.

Sedangkan saling pengertian adalah sikap saling memahami kelebihan dan kekurangan masing-masing, dapat bekerjasama dan tidak egois. Sikap saling pengertian juga dapat menumbuhkan solidaritas yang tinggi.

Jika kedua hal ini diterapkan dalam proses pembelajaran terutama pada pembelajaran multikultural, maka akan menimbulkan kenyamanan dan kemanan, juga berpengaruh terhadap hasil dari proses pembelajaran yang dilakukan.

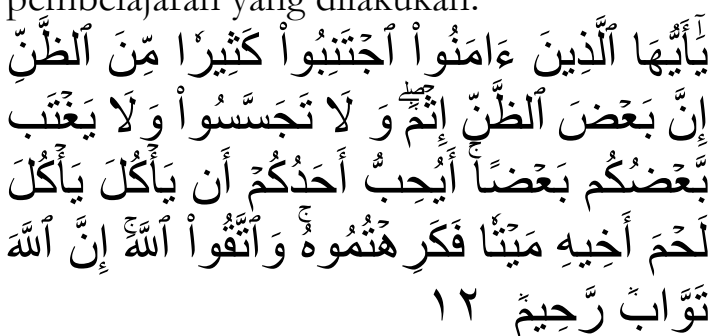

"Hai orang-orang yang beriman, jauhilah kebanyakan purba-sangka (kecurigaan), karena sebagian dari purba-sangka itu dosa. Dan janganlah mencari-cari keburukan orang dan janganlah menggunjingkan satu sama lain. Adakah seorang diantara kamu yang suka memakan daging saudaranya yang sudah mati? Maka tentulah kamu merasa jijik kepadanya. Dan bertakwalah kepada Allah. Sesungguhnya Allah Maha Penerima Taubat lagi Maha Penyayang" (Q.S. AlHujurat: 12)

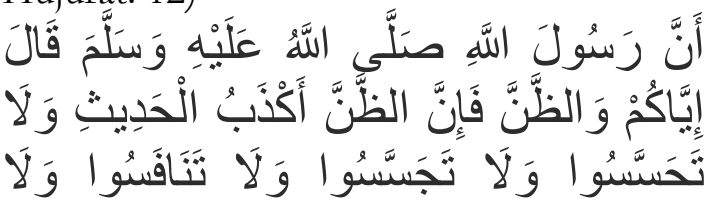

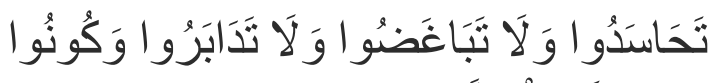

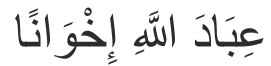
Sesungguhnya rasulullah SAW. pernah bersabda: "Jauhilah berprasangka buruk, karena prasangka buruk adalah ucapan yang paling dusta. Janganlah mencari-cari isu: janganlah mencari-cari kesalahan: janganlah saling bersaing: janganlah saling mendengki: janganlah saling memarahi: dan janganlah saling membelakangi (memusuhi)! Tetapi, jadilah kalian hamba-hamba Allah yang bersaudara" (H.R. Muslim, Ahmad)

Sikap saling percaya dan saling pengertian dapat dimaknai saling melindungi, saling memahami, saling tolong menolong dalam kebaikan bukan saling tolong menolong dalam keburukan, sebagaimana perintah Allah dalam Q.S. AlMaidah ayat 2.

"Dan tolong-menolonglah kamu dalam (mengerjakan) kebajikan dan takwa, dan jangan tolong-menolong dalam berbuat dosa dan pelanggaran. Dan bertakwalah kamu kepada Allah, sesungguhnya Allah amat berat siksa-Nya."

\section{Toleransi}

Toleransi berasal dari kata toleran yang berarti sifat atau sikap tenggang rasa, menghargai, membiarkan, membolehkan pendirian, pendapat, pandangan, kepercayaan, kebiasaan, dan kelakuan yang berbeda atau bertentangan dengan pendirian sendiri serta tidak saling menjelek-jelekkan dalam perbedaan. (Pusat Bahasa Kemdikbud, 2011).

Dalam bahasa Arab istilah toleransi

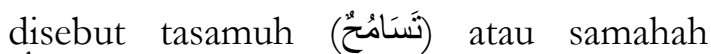

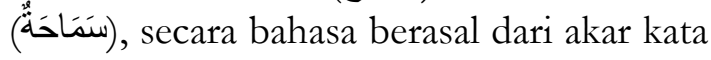
samaha (سمح). Kata samaha dan bentuk derivatifnya tidak disebutkan secara eksplisit dalam Al-Qur'an, namun disebutkan beberapa kata yang semakna dengannya seperti kata shafh (صفح) yaitu memaafkan dan ihsan (إِحسِان)yang berarti berbuat baik. Kata shafh dan bentuk derivatifnya terdapat dalam surah $\mathrm{Al}$ Baqarah ayat 109, Al-Maidah ayat 13, Al- 
Hijr ayat 85, An-Nur ayat 22 dan AzZukhruf ayat 89. Adapun kata ihsan dan bentuk derivatinya terdapat dalam surah $\mathrm{Al}$ Baqarah ayat 83 dan 195, An-Nahl ayat 90 dan 125, Al-Mu'minun ayat 96, Al-Qashash ayat $77, \mathrm{Al}$-Ankabut ayat 46 dan Fushilat ayat 43. Meski tidak disebutkan secara eksplisit dalam Al-Qur'an, kata samaha dan bentuk derivatifnya disebutkan beberapa kali dalam hadits Nabi SAW, diantaranya sebagai berikut:

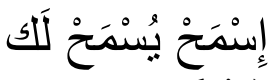

"Permudahlah (urusan orang lain) maka engkau akan dipermudah" (H.R. Ahmad)

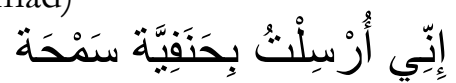

"Sesungguhnya Aku diutus dengan agama yang hanif lagi toleran." (H.R. Ahmad)

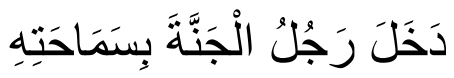

"Seorang laki-laki masuk surga karena kedermawanannya (sifat murah hati yang dimilikinya).” (H.R. Ahmad)

Toleransi berarti menghormati budaya, kepercayaan dan prinsip orang lain, toleransi ibarat tiang pondasi bagi keadilan dan kebebasan seluruh manusia. Sebagaimana rasulullah SAW bersabda.

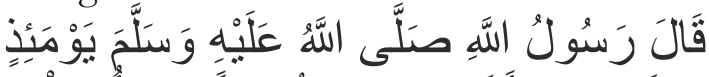

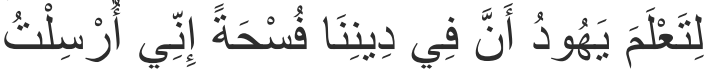

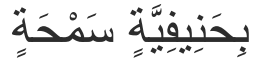

Rasulullah saw pernah bersabda: "Hendaknya orang Yahudi mengetahui bahwa di dalam agama kita terdapat kelapangan, sesungguhnya saya diutus dengan agama yang lurus yang penuh toleran.” (H.R. Ahmad)

Maka pada pendidikan multikultural ini, toleransi merupakan komponen yang penting untuk diterapkan dalam proses pembelajaran agar pendidik dan peserta didik tidak merasa mendapat tekanan yang berupa intervensi ataupun intimidasi.

\section{Diskusi}

Diskusi dalam Islam sangat disarankan untuk mencapai kesepakatan yang menguntungkan semua pihak. Dengan diskusi, maka tidak hanya mendapatkan keputusan yang menguntungkan semua pihak, tapi juga menguatkan silaturrahmi. Sebagaimana firman Allah dalam Al-Qur'an Surat Asy-Syura ayat 38.

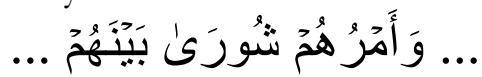

... sedang urusan mereka (diputuskan) dengan musyawarah ...

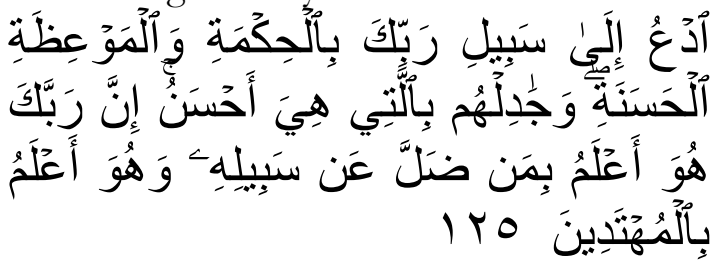

Serulah (manusia) kepada jalan Tuhan-mu dengan hikmah dan pelajaran yang baik dan bantahlah mereka dengan cara yang baik. Sesungguhnya Tuhanmu Dialah yang lebih mengetahui tentang siapa yang tersesat dari jalan-Nya dan Dialah yang lebih mengetahui orang-orang yang mendapat petunjuk (Q.S. AnNahl: 125)

Secara tersirat, ayat ini menjelaskan etika berdiskusi dengan cara-cara yang bijak, santun, dan dengan teladan baik. Seandainya terjadi perdebatan dan bantahan, maka bantahlah dengan cara yang lebih baik, bukan dengan cara-cara kasar, emosional, dan kebencian.

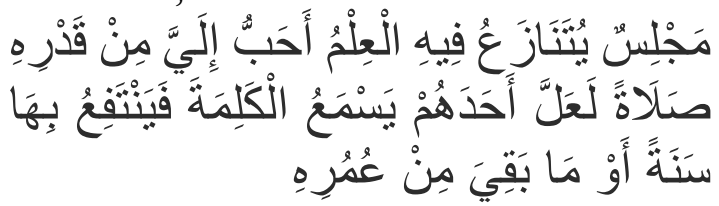

"Majelis yang diselenggarakan untuk mendiskusikan ilmu lebih aku sukai daripada digunakan untuk shalat (sunnah), sebab siapa tahu diantara kalian mendengar sepatah kata yang manfaatnya bisa setahun atau sepanjang umur" (H.R. Darimi)

\section{Kesimpulan}

Indonesia sebagai negara yang memiliki keragaman etnik, ras, suku, budaya, dan bahasa merupakan 
multikultural yang harus disikapi dengan solusi. Model pendidikan multikultural, diharapkan dapat menciptakan sikap toleransi terhadap budaya dan etnis seluruh bangsa Indonesia.

Penerapan pendidikan multikultural dilaksanakan dengan mendesain proses pembelajaran, mempersiapkan kurikulum dan desain evaluasi, serta mempersiapkan pendidik yang memiliki persepsi, sikap dan perilaku multikultur, sehingga menjadi bagian yang memberikan kontribusi positif terhadap pembinaan sikap multikultur para peserta didiknya.

Selain harus memiliki pengetahuan serta paham nilai-nilai multikultural, tenaga pendidik harus mempunyai kompetensi dalam menyampaikan nilai-nilai tersebut, baik dalam wilayah kognitif, afektif maupun psikomotoriknya serta mampu secara profesional mengajar mata pelajaran, menanamkan nilai-nilai multikultutal untuk tercapainya pendidikan yang demokratis dan humanis.

Komponen-komponen penting yang diperlukan untuk mencapai tujuan dimaksud pada pendidikan multikultural, yaitu: 1) Memperkuat persamaan daripada perbedaan, 2) Saling percaya dan saling pengertian, 3) Toleransi terhadap perbedaan, 4) Berdiskusi bukan memaksakan pendapat.

Memperkuat persamaan daripada perbedaan adalah komponen yang harus menjadi prioritas dalam pendidikan multikultural. Persamaan dimaksud adalah persamaan sebagai manusia ciptaan Alllah, tidak melihat status, ras, warna kulit dan lain sebagainya. Karena siapapun manusia itu, mempunyai hak dan kewajiban yang sama terhadap Allah SWT.

Untuk menumbuhkan rasa saling percaya dan saling pengertian di dalam lingkungan belajar memang tidaklah instant perlu proses yang dimulai dengan membuat nyaman dan aman baik untuk pendidik maupun peserta didik.
Selanjutnya akan tumbuh sikap toleransi antara pendidik dan peserta didik atau antar peserta didik.

Setiap masalah yang muncul dalam lingkungan belajarnya akan didiskusikan dan dimusyawarahkan bersama tanpa ada saling mengungguli dan saling menjatuhkan.

Apabila konsep Pengelolaan Pembelajaran berdasarkan komponen multikultural tersebut disertai dengan dukungan model, media, metode dan strategi yang tepat maka proses pembelajaran diharapkan dapat berhasil dengan baik dan maksimal.

\section{DAFTAR PUSTAKA}

Al-Khalidi, S. A. F. (2017). Mudab Tafsir Ibnu Katsir. Maghfirah Pustaka.

Al-Sheikh, A. bin M. bin A. bin I. (2005). Tafsir Ibnu Katsir [1-8] (A. Ghoffar (ed.)). Pustaka Imam Syafi'i.

Arifin, M. (2014). Ilmu Pendidikan Islam: Tinjauan Teoritis dan Praktis Berdasarkan Pendekatan Interdisipliner. Bumi Aksara.

Ashadi, W. (2017). Pendidikan Agama Islam Berperspektif Multikultural (Studi di Sekolah Dasar Tumbuh 1 Yogyakarta). Ta'dib: Jurnal Pendidikan Islam, 6(1), 93-100. https://doi.org/10.29313/tjpi.v6i1. 2537

Asy-Syaukani, M. ibn A. ibn M. (n.d.). Tafsir Fathul Qadir [1-12] (S. Ibrahim (ed.)). Pustaka Azzam.

Ath-Thabari, A. J. M. bin J. (2009). Tafsir Ath-Thabari (A. Somad \& A. Supandi (eds.)). Pustaka Azzam.

Az-Zuhaili, W. (2013). Tafsir Al-Munir [115] (A. H. Al-Kattani (ed.); 1st ed.). Gema Insani Press.

Hamka, H. A. M. A. K. A. (1982). Tafsir AlAzhar [1-10]. Pustaka Nasional PTE LTD.

Hanafi. (2016). Multikulturalisme dalam alQur'an, Hadits, dan Piagam Madina. Saintifika Islamica, 3(2), 169-191. 
Iwan Hermawan, Uus Ruswandi, Mohamad Erihadiana /_Ta'dib: Jurnal Pendidikan Islam,

Vol. 9 No. 1 (2020) 63-76

ISSN 1411-8173 | E-ISSN 2528-5092

https://ejournal.unisba.ac.id/index.php/tadib/article/view/6233

http://jurnal.uinbanten.ac.id/index .php/saintifikaislamica/article/dow nload/97/99/

Hermawan, I. (2019a). Metodologi Penelitian Pendidikan (Kualitatif, Kuantitatif dan Mixed Method). Hidayatul Quran. https://books.google.co.id/books? $\mathrm{id}=\mathrm{Vja} 4 \mathrm{DwAAQBAJ}$

Hermawan, I. (2019b). Teknik Menulis Karya Ilmiah Berbasis Aplikasi dan Metodologi. Hidayatul Quran. https://books.google.co.id/books? $\mathrm{id}=\mathrm{ciO}-\mathrm{DwAAQBAJ}$

Hidayatullah, A.-A. A. (2012). Implementasi Pendidikan Multikultural Dalam Praksis Pendidikan Di Indonesia. Jurnal Pembangunan Pendidikan: Fondasi Dan Aplikasi, 1.

Irhandayaningsih, A. (2012). Kajian Filosofis Terhadap Multikulturalisme Indonesia. Jurnal Humanika, Vol 15, No. https://doi.org/https://doi.org/10 .14710/humanika.15.9.

Mahfud, C. (2011). Pendidikan Multikultural. Pustaka Pelajar.

Pusat Bahasa Kemdikbud. (2011). Kamus Besar Bahasa Indonesia. Pusat Bahasa Departemen Pendidikan Nasional. http://www.kamusbesar.com/386 43/surealisme

Shihab, M. Q. (2007). Wawasan Al-Qur'an: Tafsir Tematik atas Pelbagai Persoalan Umat. Mizan Pustaka.

Shihab, M. Q. (2008). Tafsir al-Mishbah; Pesan, Kesan, dan Keserasian AlQuran. In 4. Lentera Hati.

Sulalah. (2011). Pendidikan Multikultural Didaktika Nilai-nilai Universitas Kebangsaan (1st ed.). UIN Maliki Press.

Supadie, D. A., \& Sarjuni. (2011). Pengantar Studi Islam. Raja Grafindo Persada.

Tilaar, H. A. . (2014). Multikulturalisme, Bahasa Indonesia, Dan Nasionalisme Dalam Sistem Pendidikan Nasional. Jurnal Dialektika, 1(2), 213-224. https://doi.org/10.15408/dialektik a.v1i2.6287

Tim Fokusmedia. (2015). Undang-Undang SISDIKNAS Sistem Pendidikan Nasional. Fokus Media.

Tobroni. (2007). Pendidikan Kewarganegaraan: Demokrasi, HAM, Civil Society dan Multikultural. PuSAPoM.

Warsah, I. (2017). Kesadaran Multikultural sebagai Ranah Kurikulum Pendidikan. Ta'dib: Jurnal Pendidikan Islam, 6(2), 29-38. https://doi.org/10.29313/tjpi.v6i2. 2845

Wihardit, K. (2010). Pendidikan Multikultural: Suatu Konsep, Pendekatan Dan Solusi. Jurnal Pendidikan, 11(2), 96-105. https://doi.org/10.33830/jp.v11i2. 561.2010

Zamroni. (2011). Pendidikan Demokrasi Pada Masyarakat Multikultural. Gavin Kalam Utama. 